\title{
THE LACTIC ACID AND GLUTATHIONE CONTENT OF THE BLOOD OF SCHIZOPHRENIC PATIENTS ${ }^{1}$
}

\author{
By JOSEPH M. LOONEY AND HAZEL M. CHILDS \\ (From the Memorial Foundation for Neuro-Endocrine Research and the Research \\ Service, Worcester State Hospital, Worcester)
}

(Received for publication June 11, 1934)

The theory that schizophrenia is due to a deficient oxidation of the body tissues particularly in the hypothalamic region of the brain has been the starting point for a number of investigations. In support of this theory it has been demonstrated (1) that the rate of oxygen consumption of schizophrenic patients is significantly lower than that of normal subjects. This decreased intake of oxygen is not infrequently (2) accompanied by a lowering of the venous oxygen content of the blood. McFarland (3) has shown that when normal individuals are subjected to a lowered oxygen tension for a short time they tend to react in a manner very similar to schizophrenic patients.

In view of these facts it was felt that a study of the lactic acid content and also of the oxidative enzymes of the blood might shed further light on the problem. Even though sufficient oxygen were made available, a deficiency in amount of glutathione which is a general cell catalyst that facilitates oxidation-reduction reactions might interfere with the utilization of this oxygen by the tissues and thus lead to an accumulation of lactic acid.

The investigation was carried out on a group of 37 schizophrenic patients and 18 normal subjects. The patients were all males, between the ages of 20 and 45, free from all evidences of ordinary organic disease such as could be detected by a careful physical examination and a thorough study of the blood and urine by exhaustive laboratory procedures. All cases in which the diagnosis of schizophrenia was not agreed to by the diagnostic staff of three or more psychiatrists, several internists, and two psychologists-both of the latter groups being well versed in practical psychiatry-were excluded from the study. The normal subjects consisted of male physicians, attendants, medical students, and employees of the hospital. These were all presumably healthy individuals and free from acute infections at the time of the test.

The blood samples were all taken from the median basilic vein, with-

${ }^{1}$ A report on this work was presented before the meeting of the American Society of Biological Chemists at New York, March, 1934. 
out stasis, which was avoided by waiting for at least one minute after the removal of the tourniquet used to facilitate entrance into the vein.

The subjects reported for the test in the morning, in a fasting condition, and then reclined quietly in bed for 30 minutes before the blood samples were taken.

The amount of total and reduced glutathione was determined by the method of Woodward and Fry (4) on sulfosalicylic acid filtrates; the lactic acid analyses were made by the method of Friedemann and Kendall (5). The gas analyses were made by the manometric method of Van Slyke. All analyses were made in duplicate from blood collected and stored in a capped syringe in the manner described by Looney and Childs (6).

An analysis of the technical errors involved in the determination of lactic acid and also of glutathione indicated that these were entirely negligible, as about 80 per cent of the duplicate determinations on the same blood sample differed by only $0.5 \mathrm{mgm}$. and about 90 per cent of the double runs varied less than $1.0 \mathrm{mgm}$. Some difficulty was encountered in the lactic acid determinations owing to the fact that oxidizable materials in the laboratory air gave excessively high blanks, but this was readily overcome by the insertion into the system of two wash bottles, the first containing bisulfite solution and the second permanganate solution, so that all air carried through the apparatus had first to pass through these wash bottles. Since the introduction of this modification the recovery of lactic acid, added in the form of lithium lactate, has varied from 99 per cent when $20 \mathrm{mgm}$. were added to 96 per cent when $10 \mathrm{mgm}$. were added.

The distribution constants for the various constituents studied are given in Table $I$ for the venous blood of the patients and of the control subjects. There is a significant difference between the mean value of $59.30 \pm 0.47$ volumes per cent for the carbon dioxide content of the blood of the patients, and that of $54.12 \pm 0.86$ volumes per cent for the control subjects. The difference for the venous oxygen content is 1.38 volumes per cent, the mean for the patients being $8.74 \pm 0.38$ volumes per cent and that for the normal subjects being $10.12 \pm 0.67$ volumes per cent. The sample taken from the patients' group is not representative of the schizophrenic population as a whole in respect to blood gases since patients showing low venous oxygen values on previous studies were purposely chosen for this investigation.

The mean value for the lactic acid content of the venous blood of the patients was $14.27 \pm 0.72 \mathrm{mgm}$. per cent, while that for the control. subjects was $10.28 \pm 0.57 \mathrm{mgm}$. per cent. The distributions for both groups are shown in Figure 1. The difference, $4.00 \pm 0.92 \mathrm{mgm}$. per cent, exceeds its standard error by more than four times and is therefore statistically highly significant. With a larger sample the difference might be somewhat smaller than that found in this study because many of the high values seemed to occur among the early determinations. But even 
TABLE I

Constants of distributions pertaining to venous gases, lactic acid, etc. of schizophrenic patients and normal controls

\begin{tabular}{|c|c|c|c|c|c|c|}
\hline & & $\underset{\text { ber }}{\text { Num- }}$ & $\begin{array}{l}\text { Mini- } \\
\text { mum }\end{array}$ & $\underset{\text { mum }}{\text { Maxi- }}$ & 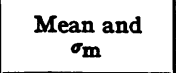 & $\begin{array}{l}\text { S.D. and } \\
\sigma_{\text {B D. }}\end{array}$ \\
\hline \multirow{2}{*}{$\mathrm{CO}_{2}$, volumes per cent } & Patients & 51 & 53.25 & 73.09 & $59.30 \pm 0.47$ & $3.33 \pm 0.333$ \\
\hline & Controls & 17 & 49.72 & 63.52 & $54.12 \pm 0.86$ & $3.44 \pm 0.61$ \\
\hline \multirow{2}{*}{$\mathrm{O}_{2}$, volumes per cent } & Patients & 51 & 4.21 & 15.69 & $8.74 \pm 0.38$ & $2.69 \pm 0.269$ \\
\hline & Controls & 17 & 6.78 & 17.53 & $10.12 \pm 0.67$ & $2.69 \pm 0.48$ \\
\hline \multirow{2}{*}{$\begin{array}{l}\text { Reduced glutathione, } \\
\text { mgm. per cent }\end{array}$} & Patients & 53 & 25.00 & 45.40 & $34.99 \pm 0.68$ & $4.90 \pm 0.45$ \\
\hline & Controls & 18 & 31.30 & 47.90 & $38.23 \pm 1.20$ & $4.96 \pm 0.85$ \\
\hline \multirow{2}{*}{$\begin{array}{l}\text { Total glutathione, } \\
\text { mgm. per cent }\end{array}$} & Patients & 49 & 27.90 & 50.30 & $39.12 \pm 0.71$ & $4.94 \pm 0.5$ \\
\hline & Controls & 18 & 33.80 & 51.80 & $41.91 \pm 1.25$ & $5.14 \pm 0.88$ \\
\hline \multirow{2}{*}{$\begin{array}{l}\text { Lactic acid, mgm. per } \\
\text { cent }\end{array}$} & Patients & 57 & 6.70 & 38.40 & $14.27 \pm 0.72$ & $5.35 \pm 0.51$ \\
\hline & Controls & 18 & 6.10 & 13.90 & $10.28 \pm 0.57$ & $2.33 \pm 0.40$ \\
\hline
\end{tabular}

when these values are excluded the difference still remains significant. The standard deviation for the patients of $5.35 \pm 0.51 \mathrm{mgm}$. per cent is more than twice as great as the value obtained for the normal subjects of $2.33 \pm 0.40 \mathrm{mgm}$. per cent. The lactic acid content of the blood of schizophrenic patients is, therefore, not only higher than that of normal subjects but is also subject to much greater variation among individuals.

The mean of reduced glutathione for the patients was $34.99 \pm 0.68$ mgm. per cent, while that for the normal subjects was $38.23 \pm 1.20 \mathrm{mgm}$. per cent. The difference is $3.24 \mathrm{mgm}$. per cent, while the standard error of this difference is $1.38 \mathrm{mgm}$., so that the difference exceeds its standard error only 2.3 times, which indicates that a similar difference could occur by chance about once in forty trials, and as most statisticians require that the possibility that the change is due to chance be no greater than one to fifty, we cannot consider that we have demonstrated a statistically significant lowering in the reduced glutathione of the patients. As the decreased glutathione might, in part at least, account for high lactic acid values, the difference may be regarded as of some physiological importance.

The mean values for total glutathione were $39.12 \pm 0.71 \mathrm{mgm}$. per cent for the patients, and $41.91 \pm 1.25 \mathrm{mgm}$. per cent for the normal subjects. The difference of $2.79 \mathrm{mgm}$. per cent is not statistically significant.

The values for the constituents in the arterial blood are given in Table II. It will be noted that the amounts of total glutathione and reduced 


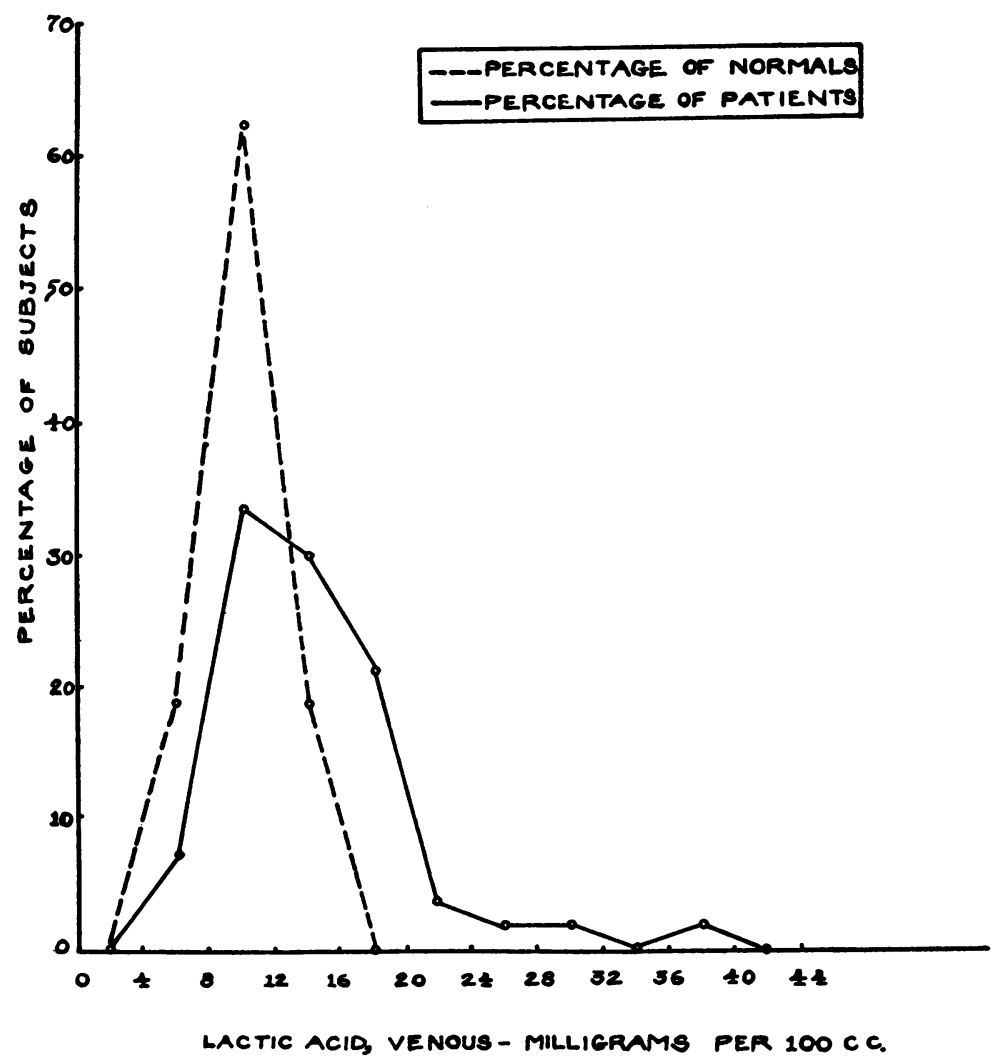

Fig. 1. Distribution of Venous lactic Acid Values in Normal Subjects and Patients

glutathione are practically the same as in the venous blood, the slight difference shown being only about one-half the standard error. The lactic acid content has dropped to $11.81 \pm 0.61 \mathrm{mgm}$. per cent. The oxygen content and the carbon dioxide content of the arterial blood agree with the values obtained in our previous study.

TABLE II

Constants of distributions pertaining to arterial gases, lactic acid, etc. of schirophrenic patients

\begin{tabular}{|c|c|c|c|c|c|}
\hline & $\underset{\text { ber }}{\text { Num- }}$ & $\begin{array}{l}\text { Mini- } \\
\text { mum }\end{array}$ & $\underset{\text { mumi- }}{\text { Maxi- }}$ & $\begin{array}{l}\text { Mean and } \\
\sigma_{m}\end{array}$ & $\begin{array}{c}\text { S.D. and } \\
\text { F.D.D. }^{-}\end{array}$ \\
\hline $\begin{array}{l}\mathrm{CO}_{2}, \text { volumes per cent } \ldots \ldots \ldots \ldots \ldots \\
\mathrm{O}_{2} \text {, volumes per cent } \ldots \ldots \ldots \ldots \ldots \\
\text { Reduced glutathione, mgm. per } \\
\quad \text { cent } \ldots \ldots \ldots \ldots \ldots \ldots \ldots \ldots \ldots \\
\text { Total glutathione, mgm. per cent. } \\
\text { Lactic acid, mgm. per cent. . . . . . }\end{array}$ & $\begin{array}{l}32 \\
32 \\
30 \\
30 \\
30\end{array}$ & $\begin{array}{r}42.13 \\
8.91 \\
22.00 \\
26.00 \\
5.60\end{array}$ & $\begin{array}{l}63.33 \\
22.35 \\
43.00 \\
50.60 \\
27.60\end{array}$ & $\begin{array}{l}49.73 \pm 0.76 \\
19.11 \pm 0.48 \\
35.4 \pm 0.88 \\
38.66 \pm 0.82 \\
11.81 \pm 0.61\end{array}$ & $\begin{array}{l}4.26 \pm 0.54 \\
2.68 \pm 0.34 \\
4.72 \pm 0.62 \\
4.43 \pm 0.58 \\
3.39 \pm 0.43\end{array}$ \\
\hline
\end{tabular}


A definite correlation was found between the venous and arterial lactic acid, a coefficient of 0.81 being obtained. For the correlation between venous and arterial reduced glutathione a coefficient of 0.88 was found.

As a first approximation to the solution of the problem whether the high lactic acid values in the patients were due to lack of oxygen, the coefficients of correlation were computed for the various interrelationships of the variables studied in the venous blood. No correlation was found between any of the various functions, the highest coefficient, -0.15 , being that for the relationship between lactic acid and carbon dioxide. None of the other coefficients exceeded 0.08 . The lack of correlation between the level of oxygen and that of lactic acid was somewhat surprising, as the cases studied had been picked on the basis of low venous oxygen values obtained in previous examinations. Since the lactic acid level was independent of the amount of oxygen supplied to the tissues, the high value must be ascribed to some local factor which interferes with oxidation. If a relationship had been found between the lactic acid values and the oxygen we should not be justified in stating that the high values were characteristic of schizophrenia. The failure to find such a relationship indicates that the method of choosing the cases for study had no influence on the results so that the sample may be considered as a truly random one in respect to lactic acid.

The work of Margaria, Edwards, and Dill (7) has shown that the concentration of lactic acid in venous blood is proportional to the amount of lactic acid in the tissues. The high values of lactate noted by us, therefore, indicate an accumulation of lactic acid in the tissues. Lactic acid is an intermediate product in the oxidation of glucose. Since the abnormality cannot be ascribed to inadequate oxygen supply it must be due to something that interferes with the oxidative reaction. This disturbing factor might be either a lack of oxidative catalysts, or the presence of some toxic material which interferes with oxidation, or both conditions together. Part of the increase in lactic acid may well be due to a lack of reduced glutathione even though the decrease in this substance is not great enough so that the difference can be held to be statistically significant. Certain evidence that we have accumulated leads us to believe that the latter factor is also operative: LeClair and Looney (8) have shown that the rate of respiration of the luminescent bacterium, Vibrio phosphorescens, is less in the presence of serum from schizophrenic patients than it is when an equal amount of normal serum is added to the suspension of bacteria.

\section{CONCLUSION}

Lactic acid is not removed from the tissues of schizophrenic patients in a basal state as readily as it is from normal subjects. This failure may be due in part to a decrease in the content of reduced glutathione. 


\section{BIBLIOGRAPHY}

1. Hoskins, R. G., Oxygen consumption ("basal metabolic rate") in schizophrenia. II. Distributions in 214 cases. Arch. Neurol. and Psychiat., $1932,28,1346$.

2. Looney and Childs. Unpublished data.

3. McFarland, R. A., Psychological effects of oxygen deprivations. Arch. Psychol., 1932, 145, 1.

4. Woodward, Gladys E., and Fry, Edith S., The determination of blood glutathione. J. Biol. Chem., 1932, 97, 465.

5. Friedemann, T. E., and Kendall, A. I., The determination of lactic acid. J. Biol. Chem., 1929, 82, 23.

6. Looney, J. M., and Childs, Hazel M., A comparison of the methods for the collection of blood to be used in the determination of gases. J. Biol. Chem., 1934, 104, 53.

7. Margaria, R., Edwards, H. T., and Dill, D. B., The possible mechanisms of contracting and paying the oxygen debt and the rôle of lactic acid in muscular contraction. Am. J. Physiol., 1933, 106, 689.

8. LeClair, Gertrude, and Looney, J. M. Unpublished data. 